\title{
News for Consumer Citizens: Corporate Pressure, Political Criticism and Middle Class Assertion in the Indian Media
}

\author{
Ursula Rao, University of New South Wales
}

Mass media have always played a crucial role for negotiating the image of the nation. This holds true also for India. My article reflects changes in the Indian media market and examines how reshaped media outlets contribute towards generating fresh images of the nation for public consumption. Mazzarella has demonstrated in a study on advertisement that media in the 1990s heavily contributed towards advancing a shift in the national imaginary from a developmentalist to a consumerist vision of the Indian nation (Mazzarella 2003: 71). The circulation of commercialised media images fosters the fermenting of a self-conscious optimistic middle class. Television provides salaried citizens with an experience of community and a platform for negotiating a common taste culture for a new India that embraces the self-orientalising image of a globally successful country, that is both culturally authentic and economically competitive (Juluri 2003; Mankekar 2000). My article focuses on this relation between media, commerce and the middle classes from the specific perspective of news making. I examine how middle class professionals contribute towards a public culture that devalues politics and hails consumerism. I argue that in a high pressure corporate environment journalists find a new voice as political commentators while accommodating within a discursive formation that promotes positive thinking about corporations, markets and commodities. The product is an uneasy compromise between a company directive, a critical ethos and a longing for a new India. 
My argument about media transformation is set against the background of market liberalisation. The economic reforms of the 1990s have created a highly successful and diverse Indian media landscape (Butcher 2003). Like electronic media, the newspaper business experienced rapid and continued growth. The availability of highly paid advertisements, coupled with radical revisions of business culture, aggressive marketing, growing political interest, an increasing literacy rate and improved technology made newspapers extremely profitable (Jeffrey 1993: 2000) and changed the approach to news making. Till the 1980s dominant news ideologies in India promoted the notion of the press as a political agent. Journalistic ethics emphasised the duty of the press to work in tandem with the political elite to modernise the nation and educate its citizens. To protect media from the vested interests of private advertisers and to ensure 'progressive' and 'objective' reporting the government massively subsidised news printing. This fostered an excessive closeness between journalists and politicians, producing tame reporting and a pro-government bias (Peterson 1996; Raghavan 1994: 142-64). What used to be the rule before liberalisation has now come under attack. Today, large regional and national newspapers are no longer dependent on political financing. The brisk growth of the advertising industry-which reached the giddy heights of over thirty percent growth per year-has supplied a highly attractive source of income (Jeffrey 2000: 58; Rajagopal 1998: 18-21). The consequences of commercialisation are more freedom in political writing at the cost of high pressure to conform to corporate interests (Sahay 2006).

Thussu (2007) eloquently describes the new environment in an analysis of the Star News program. He speaks of a process of Murdochisation, by which he means the tendency of the news program to celebrate the market, prioritise celebrity news, sports and local coverage, and minimise international news. Coverage of the corporate world is expanded at the expense of stories about interventions by government agencies. Maitrayee Chaudhuri (2010) comes to a similar conclusion in a study that covers television news and reporting in the Times of India. Her detailed content analysis demonstrates not only the proliferation of corporate news but also the pro-market bias of news texts. A particularly obvious example is a set of articles published in May 2007, following the Prime Minister's public pronouncement that companies should exercise restraint when determining CEOs salaries in a country with widespread extreme poverty. Times of India castigated this position as unreasonable. For several days it 
came out openly in defence of the industry that justified high incomes as a measure to attract talent and ensure the global competitiveness of Indian businesses.

In the following text I would like to expand the discussion of new trends in the news discourse by examining production contexts. I will demonstrate how journalists navigate the corporate environment to become serious news workers. Journalists leave no doubt that profit-seeking managers and advertising customers directly interfere with their work. However, there are also more subtle processes at work. Journalists engage with their informants and interpret their social environments as members of an upwardly mobile middle class that values professionalism and prosperity. They are worried about the excesses of a political culture that seems out of date with the demands of an emerging economy and a country that is gaining global visibility. In the following article I will depict the way journalists negotiate their evaluative gaze between corporate pressure and the desire for innovation and change.

\section{Corporate pressure and consumer fascination}

Between 1999 and 2002 I spent nine months among reporters in Lucknow, observing the making of political news in an era of expanding media markets and growing advertising revenue. Comparing my experience with accounts of journalistic practices in the pre-liberalisation years (Peterson 1996), I easily grasped the landslide transformation that had taken place. Following Nehruvian notions of journalists as partners of politicians, newspapers focused on political reporting. Journalists learned political priorities through careful initiation into the field. They began as copy editors, and gradually progressed to field reporters and political insiders. Covering the top echelons of power constituted the crowning of a career as a reporter.

The close, almost exclusive, association of (hard) news with politics is no longer a simple given in a highly dynamic Indian newspaper market. Political reporting continues, of course, to play a key role in news making, however, it competes with a range of alternative themes. In order to harvest the financial potential of the booming advertising market, corporations proliferate soft news that is considered to attract affluent and young readers, who can then be delivered to advertisers. Popular new topics are fashion, consumer goods, celebrities, health and career. Some (senior) reporters observe these changes with disdain, lamenting the dumbing down and tabloidisation as well as the uncritical adoption of corrupting western influences, like 
the sexualisation of popular culture and indulgence in cheap sensationalism. In turn, there are others who are bored with repetitive political rituals and despise the arrogant behaviour of self-indulgent leaders. A number of especially female journalists embrace the new opportunity for changing what counts as the legitimate contents of newspapers. They see soft stories as an investment in alternative journalism.

\footnotetext{
The bad thing in India is that you are recognised as journalist only if you are in political news making, when you have a lot of clout. However, the reader also wants other things. Even the television has many different channels. This does not mean that everything that is not hard news is non-serious. See for example Discovery Channel, it is so popular and it is all about serious things. (Interview with journalist 7 May 2002)
}

The endeavour to reform news discourse through thematic addition is predicated on a fundamental conflict of interests. While some believe supplements should celebrate India's achievements, provide product information to keen consumers and divert from the burdens of daily lives, others maintain that the imperative for critical reporting must apply indiscriminately to all sections of the newspaper. It is hardly surprising that these competing interpretations structure the conflict-ridden relationship between the editorial and advertisement team, or the news editor and the management. More subtle are the contentious negotiations within the community of reporters about legitimate appropriations of consumption related topics. In the following section I wish to explore how the evaluation of affluence by journalists is guided both by a commitment to critical engagement and a desire to enjoy India's entry into consumer modernity. I use the case study of a satire about a leading Indian industrialist to trace the inherent tension.

In January 2000, every single journalist in Lucknow received an oversized personal invitation to a luxurious press conference at the exclusive Sahara City, a private entertainment park of the pan-Indian industrial conglomerate, Sahara. The press conference was part of a two-week long, lavish celebration of the $50^{\text {th }}$ anniversary of the Indian Constitution organised by Subatra Roy Sahara, the owner of Sahara. I was keen to share the experience and, like approximately 200 journalists, arrived at the entry gate of the posh location. There we were greeted by the bright smiles of smartly dressed women, showered with rose petals and ushered into company-owned shuttles for a sight-seeing tour through Sahara City, which ended at a large conference building. The conference hall was decorated for a press conference. There were embellished tables, on which welcome presents had been laid: a writing pad; a large, colourful, coffee-table 
book narrating the history of the company; two expensive ballpoint pens and a bottle of mineral water. The press conference started with a long, emotionally charged lecture by Subrata Roy Sahara who elaborated on his outlook that Sahara was not an anonymous company but a family working jointly and harmoniously for the prosperity of India and the wellbeing of its citizens. The 'India Festival' was to be seen in this light, as a patriotic festival of Indians, who express their love for their country by engaging in joyous celebrations at the golden jubilee of the constitution.

The journalists were bored by the exaggerated emotionality of the presentation. Yet they listened patiently for almost one hour, before they interrupted their host and started showering him with critical questions. He was asked why he wasted such excessive amounts of money on this festival instead of investing in social betterment. Reporters demanded justification for excluding the public from this so-called 'India Festival.' Why not call it the 'Sahara Festival,' when all it does is showcase the company and its director? Subrata Roy Sahara had to defend his involvement in the media business. Why call his newspaper Sahara, making a direct connection with the company? Why create another television channel that will be no different from all the others? He was accused of cheating and bribing, and was grilled about his dispute with the tax department and his conflict with former Chief Minister Kalyan Singh. In spite of the hostile atmosphere, Subrata Roy Sahara remained calm, trying hard to present himself as a visionary. Only occasionally did he lose patience and scoffed at the journalists for their negative and ever suspicious attitude. He explicitly asked for positive publicity and received it in all publications the next day. Times of India reported about the impressive way 'Sahara [had] let its hair down in style!' (28 January 2000), even if with a somewhat cynical undertone. The real surprise came a day later when a critical essay signed by Maria exposed the tension that prevailed during the event.

\footnotetext{
A midsummer night's dream or as you like it!

Nobody does anything for the others. On the contrary everyone does everything for the self. They do it for either material or spiritual gain and they do it to avoid material or spiritual loss. That is why nobody ever makes any sacrifice for others. [...] Plato's 'Philosopher King' may or may not have left any imprint but Subrata Roy 'Sahara' leaves no opportunity to air his philosophy on virtually everything under the sun. At a press conference on Thursday, he once again launched on an exposition of 'Anand' [joy] or pleasure. His 'anand,' however, is no hedonistic voyage, he claimed, even though some pressmen thought he was indulging in a vulgar display of wealth.
}

Even as belligerent journalists labelled Sahara's ongoing 'India Festival' as a mindless waste of money and resources, Roy spoke of the joy of celebration and of giving into the spirit of gay 
abandon. Journalists as a group are difficult customers at the best of times. And Roy's sermon on Sahara did nothing to douse their hostility. He was questioned at the purpose behind the show, on the politics of the show and on the money he had squandered. Mr Roy was patience personified. 'In a wedding,' said he in well modulated and deep throated voice, 'the expenditure can never really be determined. And here I am celebrating the day when Indian Constitution came into force. How can I really define monetary parameters for this joyous occasion. The details of expenditure will be available only after the festival comes to an end,' he explained.

Journalists smirked and giggled while some of them asked, somewhat rudely, if the money could have been put to better use. Journalists seemed to suggest that they did not really need a lesson on seeking pleasure. Roy remained unfazed. 'We have specific budgets for social and welfare activities.' $[\ldots]$

Why call it a Bharat Parva [India Festival] when all that it was showcasing was Sahara and Saharashri [Mr. Sahara], was the snide question that was hurled at him next. The man seemed to have rehearsed his reply. 'Artists from all over the country have gathered under one roof and the subsequent mingling of cultural fragrances is surely reason enough to call it a festival of India,' he added.

What was the nature of his difference with former chief minister Kalyan Singh, jeered a newsman while another reporter wondered how he managed to get government officials transferred at the drop of a hat. Others reminded him of his hobnobbing with politicians [...]. Roy brushed them off like water shaking from a duck's back. With a perpetual smile plastered on his face, he acted the perfect host, not losing his cool, patiently explaining that none of the charges against him had ever been proved [...]. 'The man is a fraud,' fumed a reporter while another protested, 'Ha! why doesn't he spend all his money on the welfare of the poor... see, he has an obsession with films; everything is so "filmi" about him ... his "shahar" [resort], his guests, his show ...,' while a fourth one reminded the group that Roy had indeed created employment for several hundred thousand people. 'You cannot say the same thing about the government,' he scoffed. The final word may not have been spoken yet. The debate on the enigma that is Subrata Roy 'Sahara,' meanwhile, continues unabated. Will the real Subrata Roy please stand up? (Times of India, 29 January 2000)

Subatra Roy Sahara was infuriated. During a personal interview with the editor of the Times of India, I later learned that he personally rang the head office in Bombay to withdraw the company's advertisements from all editions of the newspaper countrywide. The headquarters passed the pressure on to the Lucknow editor and commanded him to tame his team. While journalists in Lucknow smirked about their coup, they did change their style of reporting. On successive days two stories appeared, marvelling about the beauty of Sahara City (Times of India, 31 January and 1 February 2000), illustrated with romantic pictures of its most stunning sites. The drastic intervention confirms what journalists regularly attest, that corporate customers directly intervene into daily reporting and that appeasement of private industry is the first principle of commercial newsmaking.

However, the internal evaluation of Maria's piece suggests that the positive depiction of industry partners is not a mere mechanical reaction to institutional pressure. After listening to the hostile questions at the press conference, I expected that reporters would admire Maria for attacking the 'giant' and secretly congratulate her for the analytical 
piece. This expectation was informed by prior observations about the glee with which journalists enjoyed political satire. However, my anticipation was wrong. Journalists castigated Maria's negative attitude towards the generous host. In view of all the political misery, here is finally an example of India's excellence. Can't she be proud of her own country? Journalists were clearly fascinated by the dazzling world of luxury and stardom. The Sahara press conference was the perfect place to observe the positive appraisal of affluence among a majority of journalists.

Unlike reporters I had not received an invitation to the event. However, there was no way a keen observer could have missed it. When I arrived in the press room on the morning of the 27 January 2000, I was still unaware of the Sahara programme. I had prepared myself for another routine day with politicians, but sensed immediately that something special was going on. The atmosphere was laden with expectation and excitement. Everyone talked about Sahara City, about which there were many rumours but little first-hand knowledge. No one had ever set foot in this fortress, which was reserved for the meetings of the very powerful and rich. Suddenly there was a chance to enjoy a lavish lunch at the most elitist place in the city, invited by the man who has it all—money, power and influence.

Journalists' expectations were not disappointed. They were impressed by the resort and relished the deluxe Indian cuisine. After this uplifting experience, reporters could not reconcile themselves with the 'negative attitude' of Maria towards a host who had offered the most fantastic service. What the team from the Times of India described as 'garish' or a 'vulgar display of wealth' was for most others an impressive show of affluence. Subrata Roy Sahara appeared as the perfect role model, a self-made man who had started a small company to become one of the richest men in the country. The fascination with the shooting star, however, did not translate into naïve belief in the benevolence of corporate magnates. The extremely hostile atmosphere during the press conference proves that journalists are suspicious of Subatra Roy Sahara, who is accused of tax fraud and of massive involvement in the black economy and is believed to exploit his employees. Yet, journalists felt that they did not have a concrete reason to bring this up at a time when the host had given them a perfectly good occasion to highlight his amazing success story. They spoke admiringly about someone who donates from his profits for good causes; unlike politicians who are seen to re-appropriate others' hard 
earned rupees without fulfilling their duty to provide public service. Roy was praised for producing wealth and contributing towards India's shining success. As a powerful industrialist he embodies the longing for a different India that draws respect for its talent, competitiveness and beauty.

Indian journalists search for new measures of excellence and find impressive performances in private industry and among professionals. The positive evaluation of market successes is clearly demonstrated by regular rankings, listing the most successful, respected or richest Indians. Politicians are rarely considered in these exclusive inventories. The following example from Hindustan Times (Delhi) is a case in point. The article portraits twenty men represented as the most attractive in India and everything a woman could want 'in a single package.' To qualify, a man had to be 'well-read, well-travelled, a man of power and some wealth, sophisticated, self-assured, intelligent, articulate and experienced'-and 'good-looking' (Hindustan Times, 4 April 2004). The selection suggests that not many politicians have these combined qualities. Only three politicians made it onto the list. ${ }^{1}$ They were celebrated for their fresh and innovative style of politics. The article suggests that in the new India respect is not found primarily in politics, and certainly not in the 'old' kind of politics; rather it is generated in many other professions, ones that contribute prosperity, knowledge, security and national enthusiasm. Sportsmen, medical doctors, managers, artists and journalists are the men the nation (and women) can be proud of, look up to and follow.

In an environment that does not tolerate criticism of consumer culture, journalists find ways to embrace achievement. Why not celebrate the new female, who globally promotes Indian beauty and fashion, or the export hit Bollywood that makes Indians proud? 'We print a large beautiful photograph on the front page of the Lucknow Times every day, to give the reader a relief in the morning' (journalist, 28 March 2000). Yet, the balance between the beautiful and the critical, plain advertorial and innovative reporting, remains precarious. I remember the frustration of the editor of Times of India when he was reprimanded for printing an article about prisons on the first page in spite of the instruction not to write about places of deprivation and marginalisation. Ironically the story was about a yoga instructor who had brought respite and joy to depressed and

\footnotetext{
1 Jairam Ramesh (Congress), Saleem Sherwani (Samajvadi Party) and Sitaram Yechury (Communist Party of India [Marxist]).
} 
stressed inmates. The editor was convinced that the reporter had written a perfectly acceptable success story and saw the article as being well in line with the directive for feel-good journalism, while also making an important contribution.

The reporting about the Dalit ${ }^{2}$ leader Mayawati, president of the Bahujan Samaj Party (BSP) and intermittent chief minister of Uttar Pradesh, is another example of typical compromises with pro-consumer reporting. Journalists at Times of India disliked the heavy investment of the low class leader in statues of prominent Dalit leaders, like Ambedkar and herself. While Mayawati defended the building activity as an educational measure that would spread awareness and empower the downtrodden, Times of India routinely attacked her for wasting public funds (Loynd 2009). Yet, in a bid to highlight the beauty of Lucknow, Manoj, the reporter who had lambasted Mayawati's statues on several occasions, wrote extensively about the beauty of the expensive Ambedkar Park that glorifies Dalit, and especially BSP party, politics. When I asked Manoj about his promotional piece he replied: 'Now that the park is there, we want to point out to people why they should go there and, if they go, what they can find and what they should look for' (interview, 7 February 2000).

Many journalists are ready to embrace the global trend toward feel good journalism as a way of exhibiting India's beauty and celebrating its successes. However, their interpretation of what constitutes an achievement regularly runs into trouble with the managerial class that promotes market optimism and compliance with corporate instructions. Feel good journalism is a tool introduced by the corporation for maximising revenue and not to generate innovative perspectives and deep social reflections. The Vice-President of Bennet, Coleman \& Co. Ltd, the owner of the Times of India, leaves no doubts about what drives his management philosophy:

\footnotetext{
News or information is no longer the logic for buying newspapers... The question what will make people buy and read the newspaper is getting more and more challenging. You have to entertain them, constantly ... I tell my journalist friends that these days each headline is looked at for entertainment. And what's wrong in it? When businesses and political sentiments are down why not offer feel-good journalism? In a happy mood you consume more. And that's what every advertiser wants. (Joseph 2004: 167; see also Das 1999: 58)
}

The Sahara case exemplifies the vengeance with which Indian heavyweights interfere when they see their interests subverted. Journalists accommodate by carefully marking

\footnotetext{
${ }^{2}$ Dalit means 'downtrodden' and is used as a term for former untouchables in India who fight for the empowerment of discriminated castes.
} 
terrains. Most reporters were adamant that news corporations did not promote critical reporting. Yet, bosses were less critical of articles that did not infringe directly on the commercial interests of their paper. Hence, feel good journalism becomes the dominant genre of supplements while political reporting opens a space for critical writing.

\section{The need for political renewal}

Political satire is a new standard element of political news texts in India. I have elaborated elsewhere about how changing notions of leadership and the altered financial situation of news companies promote the writing of critical portraits of leaders (Rao 2010b). The editor of the Lucknow Times of India was particularly explicit about the need for India to leave behind a culture of hero-worshipping politicians. He instructed his employees to critically observe the political game and write from an analytical distance. Many concurred that the country needed a political renewal that would reform the corrupt, inefficient and slow state machinery. Encouragement for political critique gave journalists an opportunity to voice their frustration about the pompous behaviour of arrogant leaders, their lack of education, their manipulative behaviour, and their narrow-minded power politics.

The following article of pre-election reporting is a case in point. After listening for several days to the reports about the electoral campaigns leading up to the by-elections in the rural district of Kannauj, Aradhana could no longer contain her disgust about the extreme cynicism of the leading class. She decided to report about the 'royal' battle between the son of the polit-star and former chief minister, Mualayam Singh Yadav, and his rival, Dumpy, fielded by the popular Dalit party, BSP. As peg she used quotes from electoral speeches that exposed the disdain exhibited by the prominent politicians.

\footnotetext{
If anything goes wrong here, then this place will be strewn with dead bodies. (SP chief, Mulayam Singh Yadav, Times of India, 15 February 2000)

There have been only two powerful goondas [thugs] in the whole country-Sanjay Gandhi and myself. From where has this third goonda, Mulayam Singh Yadav, come from? (BSP candidate, Akbar Ahamad 'Dumpy')
}

Aradhana interpreted these sentences as typical expressions of a perverted political culture that invests in brute power, regardless of the costs, and is devoid of any meaningful political agenda. With her article she wanted to sharpen the critical gaze and draw attention to the growing criminalisation of politics. Her colleagues were 
impressed. They congratulated her for her frank piece and the daring exposure of widely feared men. The political heavyweight, Mualayam Singh Yadav, however, was not pleased and demanded a refutation, stating that he had been misquoted. Yet, Times of India did not comply. The next day, two follow up articles mentioned the leaders' protest in passing, but continued to castigate the manipulative behaviour of the shrewd strategist, Mualayam Singh Yadav (Times of India, 16 February 2000). Compared to the effective intervention of Subatra Roy Sahara, this is a very meek result.

This article is not a singular case. It is part of a new writing routine that exposes politics as being corrupt, criminal and inefficient (Rao 2010a). Such critical texts regularly create a ripple in the journalistic community. The case is well illustrated by the reception of the following piece that exposed the deficiency of the Chief Minister Ram Prakash Gupta, who had been dragged out of retirement to lead a party steeped in factionalism and internal conflict.

\section{Forget me not, Mr Chief Minister}

LUCKNOW: The 76-year-old chief minister of UP has a habit of forgetting things. The other day he asked his minister of state, Who are you? The minister was taken aback. But replied politely that he was Shivendra Singh, Minister of State attached to the chief minister. If you are Shivendra Singh then who is that man with curly hair, asked the chief minister referring to Rang Nath Mishra, another minister of state! [...]

The legislators have begun taking advantage of Chief Minister's memory slip. A MLC [Member of Legislative Council] said it is better to meet the CM, introduce oneself and get the work done the same day. If you take a chance then there is all possibility that the CM would ask next time 'Who are you!'

A joke going around the BJP office is that the CM has refused to contest by-elections because before the polling day he would forget from which seat he is contesting elections. [...]

Caught in this strange situation, Mr Gupta has been declared persona non grata by the BJP. Senior leaders are not even ready to discuss about the CM and his prospect of contesting elections. [...].

(Biswajeet Banerjee, Times of India, 24 January 2000)

The article was a huge success. Annu's colleagues felt that she had poignantly and eloquently summarised the headless state of the current government. The positive assessment of her article began in her own office. Times of India considered the piece to be of national importance and printed it on the front page of its Delhi edition (23 January 2000). The next day it appeared a second time in the Lucknow edition (24 January 2000). Subsequently the notion of the forgetful chief minister was circulated and re-circulated for half a year among politicians, journalists and in the media. 
Politicians from oppositional parties loved the handy phrase and began to formulate their critique of the government in terms of the described leadership crisis (Hindustan Times, 30 January 2000; Times of India, 3 February 2000; Pioneer, 24 February 2000; Sahara, 24 and 25 February 2000). Also the press continued to cash in on the popular phrase, even when not directly quoting politicians. In a background article about the state of affairs in the Lucknow government, the state correspondent of the Times of India added to earlier criticism: 'UP Chief Minister Ram Prakash Gupta emerges not only as "forgetful" but also a pale shadow of a "lost man", leaving his party men disappointed and dejected on many accounts' (Times of India, 26 February 2004). Even the BJP friendly newspaper, Dainik Jagaran, jumped on the bandwagon and confronted the Chief Minister directly with his negative image in a personal interview (Dainik Jagaran, 16 February 2000). Ram Prakash Gupta’s 'fame' also spread outside Lucknow when the popular weekly national magazine Outlook took up the theme three weeks after its first publication:

\footnotetext{
He's a relic among politicians and suffers from frequent 'memory loss.' UP chief minister Ram Prakah Gupta, also deputy CM in 1968, recently turned to his own private secretary and asked him, 'Who are you? What do you want from me?' And a few days later, he stunned union power minister R. Kumaramangalam with the poser: 'Were you in the Union cabinet when I was deputy CM?' The CM was, of course, referring to Kumaramangalam Sr. Ministers in the state cabinet are now so paranoid about the CM's forgetfulness that they don't risk leaving any work for another day. After identifying themselves, they just ask the CM to sign on the dotted line and scoot. (Outlook, 14 February 2000)
}

This selected list of cross-references demonstrates the huge success of the article. By coining a phrase, Annu fed into an ongoing debate about the decay of politics. The enthusiasm of journalists for political satire is an outcome of their intimate knowledge of the political field and the changed financial structure of newspapers. Moreover, the willingness and ability to scandalise politics is also a sign of a growing professional distance between the two professions. The English language press, in particular, has undergone a fundamental restructure of its internal operations. Following the mantras of a new global business culture, there is a strong focus on enhancing efficiency, maximising profit and creating a disciplined work force. In the new structures, reporters are exposed to high performance pressures and job insecurity. Hierarchies have been largely decoupled from seniority and promotion is merit based (Rao 2010b). Journalists moan about their high-pressure work environment and the narrow focus on profit. Yet, they also see advantages in merit-based economies, streamlined communication processes and efficient workflows. Especially the young generation has become wary of 
leadership traditions in a network society, where alliances are bought through extensive exchange relations (Price 1989). They question traditional wisdom about good leadership that demands respect for seniority, a deep commitment to particularist identities (of caste, language and religion), and the need for coercive control.

However, the very nature of political reporting makes this process of distancing an incomplete project. Journalists' own work is steeped in politics. While reporters find a new voice as critical political commentators, they simultaneously invest heavily in political relations. Proximity to leaders ensures a head start in the race for breaking news and aids the negotiation of professional and personal advantages. Critical reporting is always selective and follows careful calculations about mutual dependence. Relationships of reciprocity define one aspect of the mutual entanglement of two professions. Journalists and politicians also share a social field in which they collaboratively create 'second degree observations' (Luhmann 2000 [1996]) about politics during ongoing communications. Political dynamics are shaped through journalists' questions, comments and texts, through their presence in the field, their insistence on action, their need for drama. I have elaborated this dynamic with regard to several political events in Lucknow, where reporters' prompts contributed towards shaping political events and recreating typical expectations in the field through narrative interventions (Rao 2010a: 95-117). Journalists are both insiders and outsiders of the political process. They recreate the field through actions and comments that shape political narratives. As members of a network society, journalists play the game while reflecting on it. They are implicated in a political process on which they comment in their roles as heroes of the fourth estate.

Pushed by their employees, Indian journalists develop new themes and styles of reporting and alterative measures for success. Their role as commentators of social processes is entangled with their position as middle class professionals. Journalists gained status and income in liberal market India. As well-settled, salaried citizens they are able to see advantages in India's current economic trajectory and satisfy the directive of their management by supplying entertaining pieces about lifestyle, fashion and tourism, targeted at consumer citizens. Simultaneously, a set of young English speaking reporters has become critical of the political class. Its habits appear out of date with an emerging India. The opposition of political failure and impressive achievements 
of the market economy that emerges from the newspapers remains an incomplete testimony of the complicated internal negotiations that shape the judgements of professional observers. Journalists continue both to depend on politicians and to build and maintain networks of power of their own. Furthermore, they resent rampant commercialisation and the strict vigil that keeps market heroes out of negative news. The concluding paragraphs locate this finding in current debates about a changing public culture, dominated by the interests of the salaried classes, which is underwritten by the pro-market anti-politics position of newspapers.

\section{Conclusion}

The discussion of the alienation of the middle classes from democratic politics has received growing attention since the 1990s. The sweeping success of parties representing former untouchables and Muslims as well as the high profile efforts to increase reservations for disadvantaged castes and classes promoted a feeling among middle class people that their interests have no lobby (Jaffrelot 2003; Fernandes 2006: 182-98). Furthermore, India experienced a deepening disillusionment with Congress leadership perceived as seriously compromised by excessive corruption, nepotism and vote bank politics. Academics have documented that large sections of the middle class turned to Hindu nationalist parties, like the BJP, which promised not only a restoration of a Hindu moral order but also a radical political renewal by providing disciplined patriotic leaders who would create a business friendly environment (Hansen 1999; Rajagopal 2001). While Hindu nationalism continues to have a strong support base, the popular belief that a new generation of leaders could build a fresh, non-corrupt political culture has subsided. Repulsed by Realpolitics, middle class mobilisation has become associated with civil rather than political society (Chatterjee 2004). A current example is the proliferation of Residence Welfare Associations that mobilise against patronage networks for efficient urban governance and clean cities and of rights discourses that protect the poor (Baviskar 2003). These processes, of course, are deeply political and involve pressuring persons in power. However, this has not prevented the emergence of a popular discourse that depicts institutional politics as the 'other' of middle class professionalism, sobriety and discipline.

Reporting about corruption scandals is predicated on such an opposition between dirty politics and clean professionalism. Frequent reporting about high profile corruption 
scandals blames India's backwardness on political incompetency and a lack of commitment by the political class. High-up corruption, Mazzaella (2006) eloquently argues, is constructed as constituting the beginning of chains of events that spread from the apex of political power to infest all aspects of social life. The country needs technical solutions (e-governance) that will undermine self-serving and corrupt politicians by creating a purely technocratic state. Such narratives adopt a neoliberal position that conceives of governance as a form of abstract and detached management and that emulates the streamlined production processes of efficient corporations. It treats corruption as the pathological behaviour of individuals and political action that confirms the nexus between power, privilege and responsibility (Hasty 2005) as a sign of incomplete modernisation. Importantly, while confronting political practices from the position of a critical outsider, it naturalises an alternative set of values, which itself remains outside the reflective practices. Furthermore, it avoids a general debate about the systemic contexts that stabilise, and even demand, particular kinds of political action.

Journalism's new critical consciousness is framed by the desires of an upwardly mobile middle class that dreams about 'clean' politics, while ignoring the power constellations in an unequal society that stimulate poor people to use the political process for expressing a sense of dignity, stabilising their personal lives and gaining access to exclusive state services (Roy 2003). Significantly, it is also an expression of a fashionable position taken by members of the professional class, who experience a deep alienation from the democratic process and India's political leadership. The corporate environment of reformed news outlets underscores this development, not because it encourages critical analysis of political traditions or social trends, but by celebrating consumer culture and marginalising discussion of human rights' infringement, rural deprivation or urban poverty. Political satire is rarely on the top agenda for censorship, especially when targeted leaders are not close allies of important advertising clients. Journalists fill the spaces left void by a laissez faire attitude with sharp observations and biting critique. In turn, they tune in to corporate priorities and forestall external interference when describing India as a paradise for consumers, an ideal place for aesthetic life styles and a location that provides new opportunities for professional careers and upward mobility. The celebration of consumerism appears next to the heightened critique of politics. Such juxtaposition is not the result of a lack of critical 
consciousness, but the outcome of a compromise that accommodates the critical ethos of a writing profession within a commercialised space, while reacting to and shaping an urban, middle class attitude about a possible India.

\section{Reference List}

Baviskar, A. 2003, 'Between Violence and Desire. Space, Power, and Identity in the Making of Metropolitan Delhi,' International Social Science Journal, vol. 175: 89-98.

Butcher, M. 2003, Transnational Television, Cultural Identity and Change. When STAR Came to India. Sage, Delhi.

Chatterjee, P. 2004, The Politics of The Governed: Reflections on Popular Politics in Most of the World. Columbia University Press, New York.

Das, B. 1999, 'The Paper Chase,' Gentleman, 57-61.

Fernandes, L. 2006, India's New Middle Class: Democratic Politics in an Era of Economic Reform. University of Minnesota Press, Minneapolis.

Hansen, T. B. 1999, The Saffron Wave: Democracy and Hindu Nationalism in Modern India. University of Princeton Press, Princeton.

Hasty, J. 2005, 'The Pleasure of Corruption. Desire and Discipline in Ghanaian Political Culture,' Cultural Anthropology, vol. 20, no. 2: 271-301.

Jaffrelot, C. 2003, India's Silent Revolution: The Rise of the Lower Castes in Indian Politics. Permanent Black, Delhi.

Jeffrey, R. 1993, 'Indian-Language Newspapers and Why They Grow,' Economic and Political Weekly, vol. 28, no. 38: 2004-11. 2000, India's Newspaper Revolution: Capitalism, Politics and the Indian Language Press 19771999. Oxford University Press, Delhi.

Joseph, A. 2004, 'The Gender Disadvantage in Indian Print Media,' in Gender and Newsroom Cultures: Identities at Work, (eds) M. de Bruin \& K. Ross, Hampton Press, Cresskill, NJ, 163-80.

Juluri, V. 2003, Becoming a Global Audience: Longing and Belonging in Indian Music Television. Peter Lang, New York.

Luhmann, N. 2000, 1996, The Reality of Mass Media. Stanford University Press, Stanford.

Loynd, Maxime 2009, 'Understanding the Bahujan Samaj Prerna Kendra: Space, Place and Political Mobilisation,' Asian Studies Review, vol. 33, no. 2: 469-82.

Mankekar, P. 2000, Screening Culture, Viewing Politics: Television, Womanhood and Nation in Modern India. Oxford University Press, Delhi.

Mazzarella, W. 2003, Shovelling Smoke: Advertising and Globalization in Contemporary India. Duke University Press, Durham, NC.

2006, 'Internet X-Ray: E-Governance, Transparency, and the Politics of Immediation in India,' Public Culture, vol. 18, no. 3, 473-505.

Peterson, M.A. 1996, Writing the Indian Story: Press, Politics and Symbolic Power in India. Brown University, Unpublished Dissertation.

Price, P.G. 1989, 'Kingly Models in Indian Political Behavior,' Asian Survey, vol. 29, no. 6: 559-72.

Raghavan, G.N.S. 1994, The Press in India: A New History. Gyan Publishing House, Delhi.

Rajagopal, A. 1998, 'Advertising, Politics and the Sentimental Education of the Indian Consumer,' Visual Anthropology Review, vol. 14, no. 2: 14-31. 2001, Politics after Television: Hindu Nationalism and the Changing of Indian Public. Cambridge University Press, Cambridge.

Rao, U. 2010a, News as Cultures: Journalistic Practices and the Remaking of Indian Leadership Traditions. Berghahn, Oxford. 2010b, 'Neoliberalism and the Rewriting of the Indian Leader,' American Ethnologist, vol. 37, no. 4: 713-25.

Roy, A. 2003, City Requiem, Calcutta: Gender and the Politics of Poverty. University of Minnesota Press, Minneapolis.

Sahay, U. (ed.) 2006, Making News. Handbook of the Media in Contemporary India. Oxford University Press, Delhi.

Thussu, D.K. 2007, 'The 'Murdochization' of News? The Case of Star TV in India,' Media, Culture and Society, vol. 29, no. 4: 593-611. 